\title{
Long-term Nocturnal Calcium Infusions Can Cure Rickets and Promote Normal Mineralization in Hereditary Resistance to 1,25-Dihydroxyvitamin D
}

\author{
Sonia Balsan, Michèle Garabédian, Michel Larchet, Anne-Marie Gorski, Giulia Cournot, \\ Cristina Tau, Agnès Bourdeau, Caroline Silve, and Claude Ricour \\ Laboratoire des Tissus Calcifiés (Centre National de la Recherche Scientifique UA.583-Institut National de la Santé et de la Recherche \\ Medicale U.30) and Department of Pediatric Gastroenterology, Hôpital des Enfants-Malades, 75015 Paris, France
}

\begin{abstract}
We report the beneficial effects of calcium infusions in a child with hereditary resistance to $1,25(\mathrm{OH})_{2} \mathrm{D}$ and alopecia. This patient after transient responsiveness to vitamin $D$ derivatives became unresponsive to all therapy despite serum $1,25(\mathrm{OH})_{2} \mathrm{D}$ concentrations maintained at levels $\sim 100$-fold normal. A 7-mo trial with calcium infusions led to correction of biochemical abnormalities and healing of rickets. Bone biopsies $(n=3)$ showed a normal mineralization and the disappearance of the osteomalacia. Cultures of bone-derived cells demonstrated a lack of activation of 25-hydroxyvitamin D 24-hydroxylase and osteocalcin synthesis by $1,25(\mathrm{OH})_{2} \mathrm{D}_{3}\left(10^{-9}\right.$ and $\left.10^{-6} \mathrm{M}\right)$. These results demonstrate that (a) even in the absence of a normal $1,25(\mathrm{OH})_{2} \mathrm{D}_{3}$ receptor-effector system in bone cells, normal mineralization can be achieved in humans if adequate serum calcium and phosphorus concentrations are maintained; and (b) calcium infusions may be an efficient alternative for the management of patients with this condition who are unresponsive to large doses of vitamin $D$ derivatives.
\end{abstract}

\section{Introduction}

Hereditary resistance to 1,25 -dihydroxyvitamin $\mathrm{D}\left(1,25(\mathrm{OH})_{2} \mathrm{D}\right)$, also termed vitamin $\mathrm{D}$ dependency type II, vitamin D-dependent rickets type II, or pseudo-vitamin D deficiency type II, is a rare condition characterized by rickets and/or osteomalacia that persist despite high circulating levels of $1,25(\mathrm{OH})_{2} \mathrm{D}(1)$. The underlying defects leading to the resistance of target tissues to $1,25(\mathrm{OH})_{2} \mathrm{D}$ have not yet been identified. Results of a recent study, in which skin fibroblast extracts from eight such patients were evaluated for the detection and quantitation of 1,25 $(\mathrm{OH})_{2} \mathrm{D}_{3}$ receptors using a monoclonal antibody to the chick receptor molecule, suggest that resistance to the hormonal form of the vitamin is the consequence of structural variations in the receptor molecule and is not due to defective receptor synthesis (2). Whatever the basic molecular defect(s), the accumulating data clearly show a great heterogeneity in the clinical features of patients with hereditary resistance to $1,25(\mathrm{OH})_{2} \mathrm{D}$ and in their response to therapy with vitamin $\mathrm{D}$ derivatives (1). Favorable

A preliminary report of this study was presented at the VIth Workshop on Vitamin D, Merano, Italy, in March, 1985.

Address correspondence to Dr. Balsan, Tour technique 6ème Etage, Hôpital des Enfants-Malades.

Received for publication 23 August 1985 and in revised form 14 January 1986.

J. Clin. Invest.

(c) The American Society for Clinical Investigation, Inc.

0021-9738/86/05/1661/07 \$1.00

Volume 77, May 1986, 1661-1667 clinical responses to the administration of pharmacological doses of native vitamin $\mathrm{D}, 25(\mathrm{OH}) \mathrm{D}_{3}, 1 \alpha(\mathrm{OH}) \mathrm{D}_{3}, 1,25(\mathrm{OH})_{2} \mathrm{D}_{3}(3-$ 10 ), or $24,25(\mathrm{OH})_{2} \mathrm{D}_{3}(11)$ have been reported in some patients. However, it has been shown that other patients with resistance to $1,25(\mathrm{OH})_{2} \mathrm{D}_{3}$ may remain unresponsive to similar therapeutic trials $(10,12,13)$ or, after prolonged remission of their symptoms, become completely refractory to treatment with vitamin $\mathrm{D}$ derivatives (10). The absence of effective therapy may have severe consequences, especially in children. Death during the first three years of life, mainly due to pulmonary complications or hypocalcemic convulsions, has been reported in six children belonging to three affected kindreds $(10,11)$. Dwarfism, skeletal deformities, myopathy, and bone pain may seriously handicap such patients $(10,14)$.

A new model for the management of patient with hereditary resistance to $1,25(\mathrm{OH})_{2} \mathrm{D}_{3}$ unresponsive to large doses of vitamin $\mathrm{D}$ derivatives is described in the present report. The evaluation of $1,25(\mathrm{OH})_{2} \mathrm{D}_{3}$ action in cultured bone-derived cells obtained from our patient at the time this treatment was initiated and 3 mo after cessation of this therapy has provided the first demonstration that, in humans, normal mineralization can be achieved even in the absence of a normal $1,25(\mathrm{OH})_{2} \mathrm{D}$ receptoreffector system in bone cells.

\section{Methods}

Patient and treatment regimens. The detailed case history of patient A up to the age of $8 \mathrm{yr}$, from November 1974 to May 1983, has been previously reported (10). This child, born in 1974 to consanguinous parents, had congenital alopecia, and indications of rickets were first seen on radiographs when she was aged $7 \mathrm{mo}$. Three of her seven siblings had previously died at $\sim 3$ yr of age with alopecia and rickets resistant to vitamin D. During high-dosage therapy with vitamin D derivatives, patient A's clinical course could be divided into three phases. Up to 3yr-old, her rickets was active, with persistant hypocalcemia hypophosphatemia and secondary hyperparathyroidism, in spite of high-dosage therapy with vitamin $D_{2}(3 \mathrm{mg} / \mathrm{d})$ or $25(\mathrm{OH}) \mathrm{D}_{3}(1 \mathrm{mg} / \mathrm{d})$. The patient then entered a recovery phase. This phase was characterized by symptomatic improvement while on $1.5 \mathrm{mg} / \mathrm{d}$ of $25(\mathrm{OH}) \mathrm{D}_{3}$, followed by correction of her biochemical abnormalities, healing of rickets, and catchup growth with therapy of 4-8 $\mu \mathrm{g} / \mathrm{d}$ of $1 \alpha(\mathrm{OH}) \mathrm{D}_{3}$. At the age of $6 \mathrm{yr}$, she again showed hypophosphatemia, increased serum alkaline phosphatase, and radiographic rickets. This relapse continued over the ensuing $3 \mathrm{yr}$ despite administration of up to $20 \mu \mathrm{g} / \mathrm{d}$ of $1 \alpha(\mathrm{OH}) D_{3}, 10 \mu \mathrm{g} / \mathrm{d}$ of $1,25(\mathrm{OH})_{2} \mathrm{D}_{3}$, and $5 \mathrm{mg} / \mathrm{d}$ of $25(\mathrm{OH}) \mathrm{D}_{3}$. Therapy with $25(\mathrm{OH}) \mathrm{D}_{3}$ induced an increase in serum $1,25(\mathrm{OH})_{2} \mathrm{D}$ levels, i.e., $11,012 \pm 4,487 \mathrm{pg} / \mathrm{ml}$ (mean \pm 1 SD of 14 determinations). $25(\mathrm{OH}) \mathrm{D}_{3}$ therapy was stopped in September 1983. 3 mo later, the child was started on a high-calcium high-lactose diet. After 5.5 mo of this regimen the patient was once more placed on a normal calcium diet and a program of nocturnal calcium infusions was begun on the 17th of May 1984. The high-calcium highlactose diet was obtained by enriching the usual normal diet of the child with dairy products (e.g., addition of powdered defatted milk to whole milk). This regimen was associated with oral supplements of $1 \mathrm{~g} / \mathrm{d}$ of 
calcium carbonate tablets and $20 \mathrm{~g} / \mathrm{d}$ of lactose. Her calculated daily intakes of calcium, phosphorus, and lactose were $2,250 \mathrm{mg}, 1,610 \mathrm{mg}$, and $62-82 \mathrm{~g}$, respectively. For the intermittent parenteral calcium infusion program, an intracaval catheter was inserted under general anesthesia. The calcium solution, i.e., 500-1,000 mg of elemental calcium as calcium glucono-galactogluconate (calcium-Sandoz ampoules, Sandoz Laboratories, Rueil Malmaison, France) in $500 \mathrm{ml}$ of $5 \%$ dextrose, was perfused from 0800 p.m. to 0800 a.m., using a peristaltic pump. The amount of elemental calcium infused was progressively increased from $500 \mathrm{mg}$ to $1,000 \mathrm{mg}$ over the first $10 \mathrm{~d}$ of nocturnal calcium infusions; this dosage was maintained for $1 \mathrm{mo}$. The patient subsequently received $750 \mathrm{mg}$ elemental calcium per $12 \mathrm{~h}$ daily for the next 4 mo. Thereafter, the treatment was continued on a thrice-weekly infusion program providing $750 \mathrm{mg}$ of elemental calcium per infusion. At the end of $\sim 6 \mathrm{mo}$ of intracaval infusions the catheter was withdrawn and the thrice-weekly nocturnal infusion therapy was continued using an arteriovenous fistula that had been created in her left forearm under general anesthesia. The calcium infusions were stopped after a total period of $7 \mathrm{mo}$.

Laboratory. Most chemical parameters were measured using automatic clinical analyzers (SMA 660 and AAI Technicon, Domont, France). Measurements of serum calcium were carried out by atomic absorption spectrophotometry (model 403, Perkin-Elmer Corp., Norwalk, CT) and serum alkaline phosphatase activity was measured using two techniques adapted to a spectrophotometer (Eppendorf Gerätebau, Hamburg, model 6121, Federal Republic of Germany) or to an autoanalyzer (Vitatron AKES, Malakoff, France). Normal ranges were 2.25$2.60 \mathrm{mmol} / \mathrm{liter}$ for calcium, and $90-300 \mathrm{IU} /$ liter or $1,500-5,000 \mathrm{nkat} /$ liter for alkaline phosphatase (15). Qualitative and quantitative analyses of amino acids in serum and protein-free urines were made with an amino acid analyzer (TSM I Technicon, Domont, France). Serum immunoreactive parathyroid hormone (iPTH) ${ }^{1}$ was measured by a modification of the method of Arnaud et al. (16) using two different antibovine parathyroid hormone-(PTH) sera. Values are expressed as purified bovine PTH equivalents. With the first antiserum, $C_{\mathrm{ll}} \mathrm{P}$, raised in our laboratory, the lower limit of detection was $0.05 \mathrm{ng} / \mathrm{ml}$. Values in normal children and adults was $<0.5 \mathrm{ng} / \mathrm{ml}$; with the second antiserum kindly supplied by Dr. J. Gueris (Hôpital Lariboisière, Paris, France), the lower limit of detection was $5 \mathrm{ng} / \mathrm{ml}$ and the normal range $15-60 \mathrm{pg} / \mathrm{ml}$. Serum 25(OH)D concentration was measured using the technique of Preece et al. (17). Serum $24,25(\mathrm{OH})_{2} \mathrm{D}$ and $1,25(\mathrm{OH})_{2} \mathrm{D}$ were measured according to Shepard et al. (18). The concentration determined by these techniques corresponds to the sum of the vitamin $D_{2}$ and $D_{3}$ forms of each metabolite. The normal ranges for children in northern France are: 6-30 ng/ $\mathrm{ml}$ for $25(\mathrm{OH}) \mathrm{D} ; 1-3 \mathrm{ng} / \mathrm{ml}$ for $24,25(\mathrm{OH})_{2} \mathrm{D}$; and $20-80 \mathrm{pg} / \mathrm{ml}$ in children between 2 and $10 \mathrm{yr}$ of age for $1,25(\mathrm{OH})_{2} \mathrm{D}(n=26)$.

Bone studies. Bone specimens were obtained from anterior iliac crests with the trepine of Bordier. Three biopsies were performed while the child was under general anesthesia for required surgical procedures, i.e., insertion of intracaval catheter, creation of an arteriovenous fistula, surgical repair of this fistula. Each bone specimen was cut longitudinally in half using a sharp lancet; one half was processed for quantitative histology, and the other used for bone-derived cell cultures.

(a) Histomorphometry. The samples were fixed in a cacodylate-buffered solution of glutaraldehyde (2.5\%) and formaldehyde and embedded in methylmetacrylate without prior decalcification. 5- and $10-\mu \mathrm{m}$ thick sections were cut with a microtome (A. O. Spencer, Buffalo, NY) equipped with a tungsten-carbide cutting edge and stained with toluidine blue $\mathrm{pH}$ 6.4) or examined, unstained, by fluorescent microscopy under a Zeiss Universal microscope. Morphometric data were obtained with a Zeiss Morphomat 10 at $\times 200$ magnification for volume data, and at $\times 500$ magnification for all other parameters studied. The following measurements were made. Bone volume, expressed as the percent of spongiosa volume composed of mineralized and nonmineralized bone matrix; os-

1. Abbreviations used in this paper: BGP, osteocalcin; HPLC, high performance liquid chromatography; iPTH, immunoreactive parathyroid hormone; PTH, parathyroid hormone; 24-hydroxylase, 25-hydroxyvitamin $D_{3}$-24-hydroxylase. teoid volume, as the percent of bone volume composed of osteoid tissue; osteoid surface, as the percent of trabecular surface covered by osteoid tissue; mineralization front, as the percent of osteoid surface showing a thin band of fine granules at the limit between mineralized and nonmineralized matrix on toluidine stained sections (at the $\mathrm{pH}$ used for the staining solution the values obtained by this method correlate closely with those obtained by tetracycline labeling [19]). Osteoblast surface was calculated as the percent of trabecular surface covered by osteoclasts; osteoclast $/ \mathrm{mm}^{2}$, as the number of osteoclasts per square $\mathrm{mm}$ of section surface. A tetracycline double labeling was performed before the third biopsy with $1 \mathrm{~g} / 24 \mathrm{~h}$ of tetracycline chlorhydrate administered according to the following schedule: $2 \mathrm{~d}$ on, $6 \mathrm{~d}$ off, followed by $2 \mathrm{~d}$ on. The biopsy specimen was taken $1 \mathrm{~d}$ after the last tetracycline intake. The mineralization rate was assessed by dividing the average distance between the two tetracycline labels (in micrometers) by the time interval between the labeling periods ( $8 \mathrm{~d}$ ), and expressed in $\mu \mathrm{m} / 24 \mathrm{~h}$. Normal values in children for the parameters measured have been previously reported (20-22).

(b) Bone-derived cell cultures. Trabecular bone specimens obtained from patient $A$ and from four age-matched controls, i.e., orthopedic patients free from disturbances of calcium and/or phosphorus metabolism, were cut into fragments ( $\sim 0.5 \mathrm{~cm}$ in diameter) and plated out into 10-cm tissue culture dishes containing modified BGJ medium (Bio-Mérieux, Lyon, France) supplemented with $30 \%$ fetal calf serum (Flow Laboratories, Puteaux, France), $100 \mathrm{U} / \mathrm{ml}$ penicillin, $50 \mu \mathrm{g} / \mathrm{ml}$ streptomycin, and $2.5 \mu \mathrm{g} / \mathrm{ml}$ fungizone (Boehringer Mannheim Biochemicals, Strasbourg, France). After $48 \mathrm{~h}$ incubation at $37^{\circ} \mathrm{C}$ in a humidified atmosphere of $95 \%$ air $/ 5 \% \mathrm{CO}_{2}$, the medium containing explants and migrating cells was filtered through sterile bolting cloth (35- $\mu \mathrm{m}$ mesh). The cell suspension thus obtained was sedimented at $400 \mathrm{~g}$ for $10 \mathrm{~min}$ in a desktop centrifuge (Hettich EBA, Ceralabo, Aubervilliers, France) and the cells resuspended in BGJ medium containing $10 \%$ fetal calf serum. They were then plated out in 3.5-cm diameter culture dishes $(n=12-20$ dishes, $10^{6}$ cells/dish) in $2 \mathrm{ml}$ modified BGJ medium supplemented with antibiotics and $10 \%$ fetal calf serum. Medium was renewed every $48 \mathrm{~h}$. The cells reached confluency after 3 to $5 \mathrm{wk}$ in culture. Confluent cells were washed once with serum-free BGJ medium and incubated in $2 \mathrm{ml}$ serumfree BGJ for an additional $6 \mathrm{~h}$ before being used for 25-hydroxyvitamin $D_{3}$-24-hydroxylase (24-hydroxylase) stimulation and osteocalcin (BGP) production tests.

24-Hydroxylase assay. The incubation medium was removed and replaced by $2 \mathrm{ml}$ fresh serum-free medium supplemented with synthetic $1,25(\mathrm{OH})_{2} \mathrm{D}_{3}$ (final concentration $10^{-9} \mathrm{M}$ ) or its ethanol solvent (not exceeding $0.2 \%$ ). After a further incubation period of $18 \mathrm{~h}$ at $37^{\circ} \mathrm{C}$, cells were incubated for $90 \mathrm{~min}$ in $5 \% \mathrm{CO}_{2} / 95 \%$ air with $0.1 \mu \mathrm{Ci}{ }^{3} \mathrm{H}$ 26,27]25(OH) $\mathrm{D}_{3}$ (Radiochemical Center, Amersham, United Kingdom; sp act $18.5 \mathrm{Ci} / \mathrm{mmol}$ ) in $0.02 \mathrm{ml}$ ethanol. At the end of the incubation, cells and their incubation medium were transferred to centrifuge tubes and extracted with methanol-chloroform (2:2, vol/vol). The methanolaqueous phase was centrifuged for $10 \mathrm{~min}$ at $600 \mathrm{~g}$, and the pellet was frozen and stored for determination of DNA content (23). The chloroform phases were dried under a stream of nitrogen, dissolved in $n$-hexaneisopropanol (92:8, vol/vol), and injected into a high pressure liquid chromatograph (Waters Associates, Milford, MA) equipped with a sample injector (model U6K) and a radial compression module RCH 100. The column, a Radial-Pak B $(8 \mathrm{~mm} \times 10 \mathrm{~cm})$ cartridge, was eluted with $n$ hexane-isopropanol at a flow rate of $3 \mathrm{ml} / \mathrm{min}$. Fractions of the effluent were collected every $30 \mathrm{~s}$ for $15 \mathrm{~min}$. An aliquot of each collected fraction was evaporated and dissolved in $5 \mathrm{ml}$ counting solution. Radioactivity in the fractions was measured using a liquid scintillation spectrometer model SL30 (Intertechnique, Plaisir, France). The putative $24,25(\mathrm{OH})_{2} \mathrm{D}_{3}$ metabolite, when detected, was further characterized by co-chromatography with synthetic $24,25(\mathrm{OH})_{2} \mathrm{D}_{3}$ on high performance liquid chromatography (HPLC) using the above system and a straight-phase system in which samples were eluted with dichloromethane-isopropanol (95:5, $\mathrm{vol} / \mathrm{vol}$ ), and by a periodate cleavage procedure (24). Results of the 24 hydroxylase assay are expressed as femtomoles of $\left[{ }^{3} \mathrm{H}\right] 24,25(\mathrm{OH})_{2} \mathrm{D}_{3}$ formed in $90 \mathrm{~min}$ per $10 \mu \mathrm{g}$ DNA. 
Table I. Biochemical Data during 25(OH)D, Therapy, After Termination of Treatment, and during the High Calcium-High Lactose Regimen

\begin{tabular}{|c|c|c|c|c|}
\hline Treatment & $25(\mathrm{OH}) \mathrm{D}_{3}(5 \mathrm{mg} / \mathrm{d} / 1 \mathrm{yr})$ & No therapy ( $3 \mathrm{mo}$ ) & High Ca-high lactose (@6 mo) & Normal range (serum) \\
\hline Calcium (mmol/liter) & $2.28 \pm 0.09(18)^{*}$ & $2.19 \pm 0.09(11)$ & $2.23 \pm 0.06(11)$ & $2.25-2.60$ \\
\hline Phosphorus (mmol/liter) & $0.82 \pm 0.09(18)$ & $0.69 \pm 0.07(11)$ & $0.76 \pm 0.09(11)$ & $1.35-2$ \\
\hline Alkaline phosphatase (IU/liter) & $2,030 \pm 308$ & $2,138 \pm 410$ & & $90-300$ \\
\hline Alkaline phosphatase (nkat/liter) & & $21,526 \pm 610(4)$ & $18,817 \pm 201(11)$ & $1,500-5,000$ \\
\hline iPTH $\left(\mathrm{C}_{n} \mathrm{P}\right)(n g / m l)$ & $0.54 \pm 0.19(6)$ & $0.57 \pm 0.09(4) \ddagger$ & & $<0.50$ \\
\hline iPTH-(53-84) $(\mathrm{pg} / \mathrm{ml})$ & & $79 \pm 25(4) \ddagger$ & $105 \pm 12.6(5)$ & $15-60$ \\
\hline 25(OH)D $(n g / m l)$ & $907 \pm 366(14)$ & $765 \searrow 16(8) \S$ & $20 \pm 3.1(3)$ & $6-30$ \\
\hline $1,25(\mathrm{OH})_{2} \mathrm{D}(\mathrm{pg} / \mathrm{ml})$ & $11,012 \pm 4,487(14)$ & $506 \searrow 89(7)^{\prime \prime}$ & $106 \pm 75(3)$ & $20-80$ \\
\hline $24,25(\mathrm{OH})_{2} \mathrm{D}(\mu \mathrm{g} / \mathrm{ml})$ & $2.34 \pm 1.28(16)$ & $2.23 \pm 1.61(8)$ & $0.9-2.3$ & $1-3$ \\
\hline
\end{tabular}

* Results are expressed as mean \pm SD when more than three measurements were made. $¥$ When the antibovine PTH(53-84) serum was used, serum iPTH was measured on the same samples using both the new and the previous $\mathrm{C}_{n} \mathrm{P}$ antiserum in order to allow comparison of the three studies periods. § The first value corresponds to serum concentration $24 \mathrm{~h}$ after the last intake of $25(\mathrm{OH}) \mathrm{D}_{3}$. "The first value for serum $1,25(\mathrm{OH})_{2} \mathrm{D}$ concentrations was obtained $1 \mathrm{wk}$ after termination of $25(\mathrm{OH}) \mathrm{D}_{3}$ therapy. Arrows indicate progressive decreases to values observed at the end of the study period.

$B G P$ production. Cells were incubated for $18 \mathrm{~h}$ in serum-free medium supplemented either with $1,25(\mathrm{OH})_{2} \mathrm{D}_{3}\left(10^{-9} \mathrm{M}\right)$ or its ethanol solvent. The medium was removed and kept frozen before subsequent BGP determination. BGP was measured (Dr. P. Delmas, Hôpital Alexis Carel, Lyon, France) using a previously described modification (25) of the radioimmunoassay described by Price and Nishimoto (26).

Informed consent was obtained from the patient's parents for all the studies and treatment described in accordance with institutional and governmental guidelines.

\section{Results}

In this patient, who had remained unresponsive to large doses of vitamin $\mathrm{D}$ derivatives for $3 \mathrm{yr}$, two different treatment regimens, i.e., high-calcium high-lactose diet and calcium infusions, were assessed.

Effect of a high-calcium-high-lactose diet. The patient was 9-yr-old, weighed $23.2 \mathrm{~kg}$, and measured $113 \mathrm{~cm}(-3.4 \mathrm{SD})$ in height when the high-calcium, i.e., $2,250 \mathrm{mg} / \mathrm{d}$, high-lactose, i.e., $62 \mathrm{~g} / \mathrm{d}$, diet was initiated. Her skeletal radiograms showed ricketic alterations, coxa vara, and genu valgum. Previous highdosage $25(\mathrm{OH}) \mathrm{D}_{3}(5 \mathrm{mg} / \mathrm{d})$ therapy had been stopped for $3 \mathrm{mo}$. The termination of high-dosage $25(\mathrm{OH}) \mathrm{D}_{3}$ therapy induced no significant changes in the biochemical parameters (Table I), although circulating concentrations of $25(\mathrm{OH}) \mathrm{D}$ and $1,25(\mathrm{OH})_{2} \mathrm{D}$ decreased from very high levels to $16 \mathrm{ng} / \mathrm{ml}$ and $89 \mathrm{pg} / \mathrm{ml}$, respectively. These observations further support the assumption that high-dosage $25(\mathrm{OH}) \mathrm{D}_{3}$ therapy had been totally ineffective from the age of $6 \mathrm{yr}$. The decrease in serum 25(OH)D concentration observed after termination of high-dosage $25(\mathrm{OH}) \mathrm{D}_{3}$ treatment (Fig. 1) would indicate a circulating half-life of $10 \mathrm{~d}$ for this metabolite. This decrease was accompanied by a parallel decrease in serum $1,25(\mathrm{OH})_{2} \mathrm{D}$ concentration with a coefficient of correlation of $r=0.98(\mathrm{p}<0.001)$. In contrast, no correlation could be found between $25(\mathrm{OH}) \mathrm{D}$ and $24,25(\mathrm{OH})_{2} \mathrm{D}$ concentrations.

The high lactose regimen given for 6 mo was well tolerated by the child, except for two short and transient episodes of diarrhea. The regimen had no significant effects on serum calcium and phosphorus concentrations or serum alkaline phosphatase activity (Table I). Serum calcium concentrations remained in the low normal range with low serum phosphorus concentrations, high iPTH, and elevated serum alkaline phosphatase. Urinary calcium excretion was similar on $25(\mathrm{OH}) \mathrm{D}_{3}$ therapy, with no therapy and on the lactose regimen $(1.21 \pm 0.46,1.26 \pm 0.6$, and $1.34 \pm 0.18 \mathrm{mg} / \mathrm{kg}$ body weight per $24 \mathrm{~h}$, respectively). The deterioration of the physical status of the patient, manifested by loss of appetite, frequent complaints of bone pain, stunted growth, and exaggeration of bony deformities observed during $25(\mathrm{OH}) \mathrm{D}_{3}$ therapy continued without apparent acceleration when this treatment was stopped and during the 6-mo period of the high-calcium-high-lactose diet.

Effect of nocturnal calcium infusions. The nocturnal calcium infusion program was carried for $7 \mathrm{mo}$, initially via an intracaval catheter and later via an arteriovenous fistula. At the end of this period, this treatment was interrupted because the child's arteriovenous fistula required surgical repair because of a stenosis due to fibrosis of the vascular endothelium. After successful repair of her fistula, the patient refused to continue the infusion program. She was left without treatment for 1 mo before high-dosage

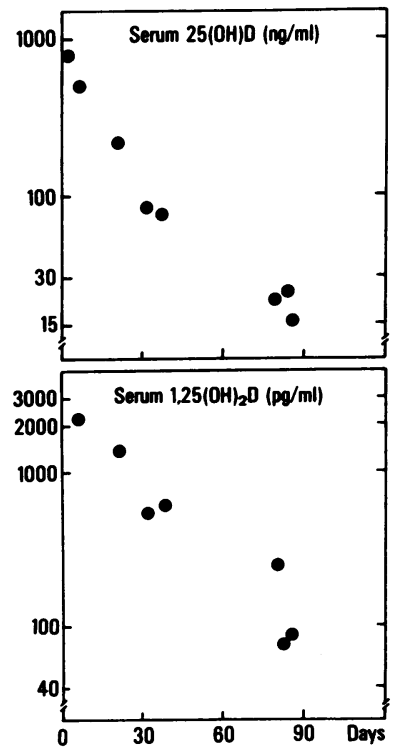

Figure 1. Serum 25(OH)D and $1,25(\mathrm{OH})_{2} \mathrm{D}$ concentration changes during the 3 mo after termination of high-dosage $(5 \mathrm{mg} / \mathrm{d}) 25(\mathrm{OH}) \mathrm{D}_{3}$ therapy. 
$(1.5 \mathrm{mg} / \mathrm{d}) 25(\mathrm{OH}) \mathrm{D}_{3}$ therapy was prescribed, and she was discharged. Thereafter, she has remained under medical surveillance (Dr. M. Touhami, Clinique A. Cabral, Oran) in Algeria.

The beneficial effects of calcium infusions on the clinical status of the patient was evident as early as 2 wk after the onset of the treatment. The child was relieved of bone pains, recovered her appetite, and became lively again. During her 7-mo therapy she gained $3.35 \mathrm{~kg}$ in weight and $3 \mathrm{~cm}$ in height vs. $0.9 \mathrm{~kg}$ and $2.5 \mathrm{~cm}$, respectively, during the preceding year.

Biochemical parameters (Fig. 2). Repeated monitoring of her serum calcium and phosphorus concentrations, i.e., every 4 $h$ during the infusion, then at the beginning and end of each infusion, and eventually once or twice weekly, showed that serum calcium remained in the normal range except for two transient episodes when it reached $2.65-2.70 \mathrm{mmol} / \mathrm{liter}$. Serum phosphorus concentrations progressively increased and remained in the normal range after 2 mo of treatment. Serum alkaline phosphatase decreased. Normalization of this parameter was obtained in the fourth month of therapy. The generalized hyperaminoaciduria with normal serum amino acid concentration observed before treatment was no longer present in the third month of treatment (not shown). Serum iPTH concentration (Fig. 2) was found to be normal after 6 mo of therapy but increased again to $76 \mathrm{pg} / \mathrm{ml}$ when the infusion regimen was stopped. Measurements of circulating vitamin D metabolites concentrations during the whole period of nocturnal infusions showed that $25(\mathrm{OH}) \mathrm{D}$ levels remained in the normal range, i.e., $9.3 \pm 2.2 \mathrm{ng} /$ $\mathrm{ml}(n=7)$. Serum $1,25(\mathrm{OH})_{2} \mathrm{D}$ concentrations were usually high, ranging from 33 to $163 \mathrm{pg} / \mathrm{ml}(112 \pm 46 \mathrm{pg} / \mathrm{ml}$, mean $\pm 1 \mathrm{SD}, n$ $=6$ ), and serum $24,25(\mathrm{OH})_{2} \mathrm{D}$ concentrations were variable: low or normal during the first month of calcium infusion, increasing to 4.5 and $7.5 \mathrm{ng} / \mathrm{ml}$ in the second and fourth month of therapy, and returning to normal, i.e., $1.4 \mathrm{ng} / \mathrm{ml}$, in the sixth month. The daily amount of calcium excreted in the urine was $\sim 15-20 \%$ of the total calcium infused. This corresponded to a urinary calcium excretion of 6-9 mg/kg body weight per $24 \mathrm{~h}$ (range in normal children $0.3-6 \mathrm{mg} / \mathrm{kg}$ body weight per $24 \mathrm{~h}$, $n=85)$.

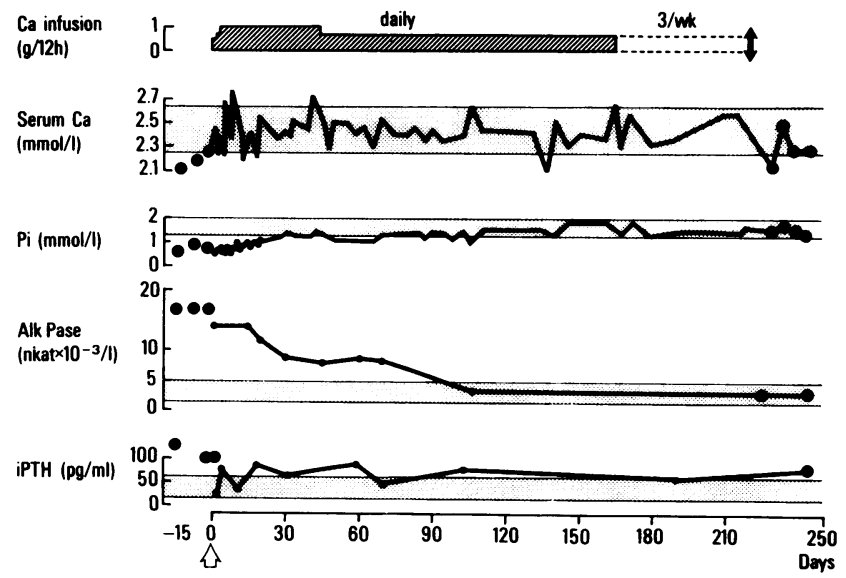

Figure 2. Biochemical data. Serum calcium (Ca), phosphorus (Pi), alkaline phosphatase (Alk Pase), and iPTH concentrations before (๑), during, and after the calcium infusion therapy. The amount of calcium infused is expressed as the amount of elemental calcium per 12$h$ infusion. The hatched area represents the normal range for each biochemical parameter.
The skeletal radiograms showed severe metaphyseal abnormalities characteristic of overt rickets and a demineralized bone with coarse trabeculations at the time the calcium infusion was initiated (Fig. $3 \mathrm{~A}$ ). $3 \mathrm{wk}$ later, the process of healing of these lesions was clearly visible (not shown). Further improvement was observed after 3 mo of nocturnal calcium infusions (not shown), leading to healing of metaphyseal lesions and restoration of a normal trabecular appearance at the end of 4 mo of therapy (Fig. 3 B). Thereafter, repeated radiological examination showed no symptoms of rickets either when the child was changed to a thrice-weekly calcium infusion program or during the 3 mo after termination of this treatment (not shown).

The morphometric data of the three bone biopsies (Table II) confirmed the dramatic changes observed in the skeletal radiograms. The initial biopsy revealed typical histological signs of severe osteomalacia, with excess osteoid volume, increased osteoid surface, and wide osteoid seams associated with a very low percentage of osteoid surface showing a mineralization front. The interface between osteoid and mineralized matrix was sharp in most trabeculae, bearing a few large calcified clusters. Occasionally, the interface was blurred and composed of large zones of fine granules and some osteoid could be observed deep within the calcified matrix. Marrow fibrosis was absent and the percent of trabecular surface covered by osteoclasts was in the normal range. Although the number of osteoclasts was increased, these were inactive in contact with the osteoid tissue. The number of osteoblasts was slightly increased. The second biopsy, obtained after 4 mo of calcium infusion therapy, showed normalization of the osteoid volume and osteoid seam thickness. Osteoid surface had decreased and the extent of the mineralization front was greatly increased as compared with the values obtained in the first biopsy. Moreover, the pattern of mineralization had become normal. The mineralization front appeared as a thin line of fine granules on toluidine-blue-stained sections, and as a clearly defined fluorescent line on unstained sections examined under ultraviolet light. The osteoclast number was found to be in the normal range. On the third biopsy, obtained after cessation of the calcium infusion program, osteomalacia had disappeared. All parameters that reflect matrix formation and mineralization, i.e., osteoid volume, osteoid surface, mineralization front, osteoid width, and mineralization rate, were not different from controls

Table II. Bone Histomorphometric Data

\begin{tabular}{lrrrc}
\hline Iliac crest biopsy* & \multicolumn{1}{c}{ I } & \multicolumn{1}{c}{ II } & \multicolumn{1}{c}{ III } & \multicolumn{1}{c}{ Controls } \\
\hline Bone volume & 21.2 & 20.6 & 20.3 & $24.2 \pm 1.6 \ddagger$ \\
Osteoid volume & 24.3 & 4.1 & 2.7 & $3.4 \pm 1.5$ \\
Osteoid surface & 84.5 & 50.5 & 23.9 & $27.9 \pm 9.1$ \\
Mineralization front & 9.7 & 47.3 & 60.4 & $70.9 \pm 5.3$ \\
Osteoid width $(\mu \mathrm{m})$ & 27.8 & 8.9 & 10.7 & $9.3 \pm 3.7$ \\
Osteoblast surface & 18.7 & 12.3 & 7.3 & $12.3 \pm 3.7$ \\
Osteoclast surface & 0.7 & 0.5 & 1.1 & $0.8 \pm 0.4$ \\
Osteoclast number/mm ${ }^{2}$ & 3 & 0.7 & 1.1 & $0.6 \pm 0.2$ \\
Mineralization rate $(\mu \mathrm{m} / \mathrm{d})$ & & & 1.2 & $1.2 \pm 0.2$ \\
& & & & \\
\hline
\end{tabular}

* Iliac crest biopsy I was obtained at initiation of the calcium infusion program; II on day 107 of this treatment; and III 3 mo after the end of this treatment.

¥ Controls values are expressed as mean \pm SD. Except for the osteoid width, the number of osteoclasts, and the mineralization front, all parameters, as defined in Methods, are expressed as percentages. 


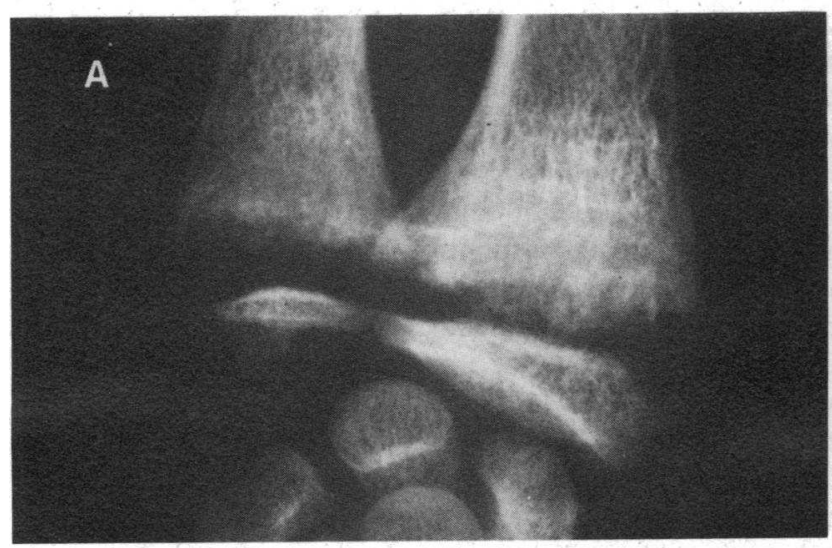

Figure 3. Skeletal X-ray data. $(A)$ A wrist radiogram at initiation of the calcium infusion program showed overt signs of rickets, demineralization with coarse trabeculation, and microcysts. A radiogram of the same wrist after $3 \mathrm{wk}$ of treatment demonstrated initiation of heal-

(Table II). A few trabeculae still contained small osteoid fragments, remnants of the earlier osteomalacic lesions.

Bone-derived cell cultures were obtained from two of the patient's iliac crest biopsies performed $24 \mathrm{~h}$ before and 3 mo after the end of the nocturnal calcium infusion program. Growth and morphology of these cultures were similar to that of control cultures $(n=4)$. In addition, the patient's cells were sensitive to PTH, as shown by increased cAMP production after incubation with bPTH-(1-34) (Silve, A., B. Groose, C. Tau, H. Garabédian, J. Fritsch, P. D. Delmas, G. Cournot-Witmer, and S. Balsan, manuscript in preparation). However, no 24-hydroxylase activity could be detected in the patient's bone-derived cell cultures (vs. 4-120 fmol/90 min per $10 \mu \mathrm{g}$ DNA in control cultures). Moreover, addition of $1,25(\mathrm{OH})_{2} \mathrm{D}_{3}\left(10^{-9} \mathrm{M}\right)$ to the culture medium of the patient bone cells was totally ineffective in stimulating 24-hydroxylase, whereas this procedure induced four- to fiftyfold increases in this activity in control cultures. Even when the concentration of the metabolite was raised to $10^{-6} \mathrm{M}$, no stimulation of the 24-hydroxylase could be obtained with the patient's bone-derived cell cultures.

The BGP levels of control cultures unstimulated by $1,25(\mathrm{OH})_{2} \mathrm{D}_{3}$ were found to be $1.5 \mathrm{ng} / 10 \mu \mathrm{g}$ DNA in two of the cultures and undetectable $(<0.5 \mathrm{ng} / 10 \mu \mathrm{g}$ DNA) in the other two. BGP value increased in all four cultures after stimulation with $1,25(\mathrm{OH})_{2} \mathrm{D}_{3}\left(10^{-9} \mathrm{M}\right)$, i.e., $4-12 \mathrm{ng} / 10 \mu \mathrm{g}$ DNA. The BGP levels measured in the cell culture obtained from the initial iliac crest biopsies of our patient were undetectable both before and after $1,25(\mathrm{OH})_{2} \mathrm{D}_{3}\left(10^{-9} \mathrm{M}\right.$ and $\left.10^{-6} \mathrm{M}\right)$ stimulation.

\section{Discussion}

The major physiological role of $1,25(\mathrm{OH})_{2} \mathrm{D}$ is to act as a calciumregulating hormone by promoting intestinal absorption of calcium and mobilization of calcium from bone $(27,28)$. This metabolite also enhances intestinal absorption of phosphorus, independent of its action on the intestinal translocation of calcium. As a consequence, most of the observed biochemical abnormalities in hereditary resistance to $1,25(\mathrm{OH})_{2} \mathrm{D}$, low serum calcium, secondary hyperparathyroidism, increased serum alkaline phosphatase, hyperaminoaciduria, and in the majority of reported observations, low serum phosphorus, derive either directly or indirectly from disturbances of the intestinal absorption of calcium and of phosphorus. Malabsorption of calcium and of

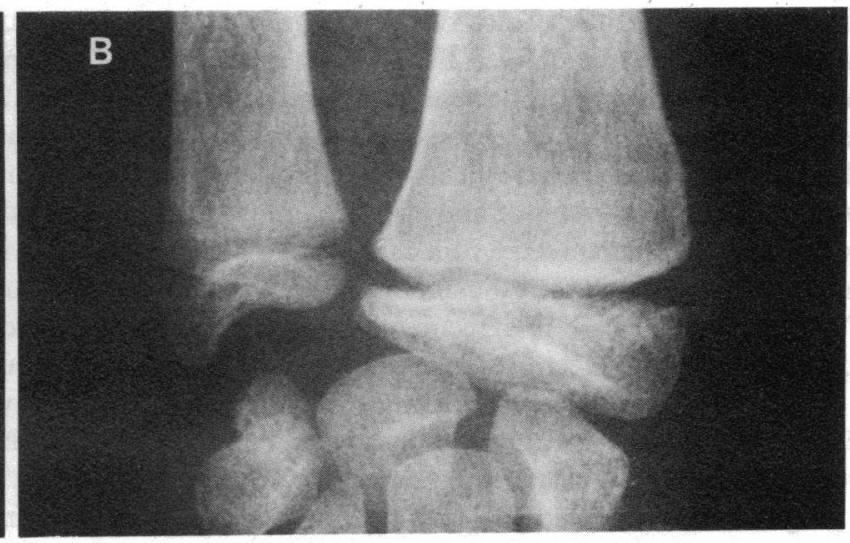

ing of the ricketic lesions. Appearance after 3 mo of nocturnal calcium infusion showed further improvement, and $(B)$ normal metaphyseal appearance and mineralization occurred after 4 mo of nocturnal calcium infusions.

phosphorus has been documented in all the patients having hereditary resistance to $1,25(\mathrm{OH})_{2} \mathrm{D}$, in whose intestinal absorption of calcium and phosphorus was investigated using external balance studies and/or fractional ${ }^{47} \mathrm{Ca}$ absorption tests $(7,8,14)$.

Intestinal absorption of calcium involves two processes, a saturable (active) transfer that is regulated by $1,25(\mathrm{OH})_{2} \mathrm{D}$ and a nonsaturable (diffusional) transfer $(29,30)$. Since, regardless of the activity of the saturable component, calcium absorption by diffusion is a linear function of lumenal calcium concentration, it is possible to overcome intestinal calcium malabsorption, at least in part, by increasing calcium intake. However, during the long-term survey of our patient and of another child with resistance to $1,25(\mathrm{OH})_{2} \mathrm{D}$, it was clear that a slight increase in serum calcium was obtained on a calcium-supplemented diet, but at the expense of a further decrease in serum phosphorus concentrations. Conversely, phosphate supplements augmented serum phosphorus but decreased serum calcium and further stimulated parathyroid hormone secretion (10). The rationale for trying a therapeutic regimen with a calcium- and lactoseenriched diet stemmed from these observations and from experimental evidence showing that lactose enhances intestinal absorption of calcium (31). This calcium- and lactose-rich diet, maintained for nearly 6 mo, was well tolerated by our patient, but its therapeutic action was nil. At the end of this period, when serum 25(OH)D returned to normal levels $(16-27 \mathrm{ng} / \mathrm{ml})$, serum $1,25(\mathrm{OH})_{2} \mathrm{D}$ concentration was found to be $89-110 \mathrm{pg} / \mathrm{ml}$ (Fig. 2). These latter values are still high as compared with those of a normal population, but not as high as those $(212-919 \mathrm{pg} / \mathrm{ml})$ reported in some untreated patients $(n=6)$ with this syndrome and with normal serum $25(\mathrm{OH}) \mathrm{D}$ concentrations $(5,7,11,12$, 32). However, these $1,25(\mathrm{OH})_{2} \mathrm{D}$ concentrations in our patient are comparable with the values we reported in another child (10) and to those $(83-132 \mathrm{pg} / \mathrm{ml})$ found in seven patients belonging to five unrelated sibships $(3,9,13,33)$. These observations further confirm the great heterogeneity of patients with hereditary resistance to $1,25(\mathrm{OH})_{2} \mathrm{D}$, and indicate that these patients do not necessarily have very high serum $1,25(\mathrm{OH})_{2} \mathrm{D}$ concentrations in the untreated state.

The effects of intermittent parenteral calcium infusions were remarkable compared to the ineffectiveness of 3-yr therapy with high-dosage vitamin $\mathrm{D}$ derivatives, and the subsequent trial with oral calcium and lactose supplementations. The decision to in- 
fuse calcium alone and the choice of the dosage of elemental calcium per infusion were derived from previous results. Approximately 100 calcium infusion tests have been performed in children with osteomalacia of various causes (Balsan, S., unpublished data). It was observed that $500-1,000 \mathrm{mg}$ of elemental calcium per one square meter of body surface, infused over 12 $h$, were well tolerated, increased serum calcium and phosphorus concentrations, and raised the tubular reabsorption of phosphorus. These observations are in agreement with the parathyroid hormone-independent effect of serum calcium levels on phosphate reabsorption and excretion demonstrated by Eisenberg (34). The present data from our patient with hereditary resistance to $1,25(\mathrm{OH})_{2} \mathrm{D}$ further confirm the previous observations. The 7-mo program of nocturnal calcium infusions normalized the child's serum calcium concentrations, progressively increased her serum phosphorus concentration, and eventually led to correction of her biochemical abnormalities and to radiological and histologic healing of her skeletal lesions. Spontaneous remission has been recently reported in a kindred with hereditary resistance to $1,25(\mathrm{OH})_{2} \mathrm{D}(35)$. However, in our patient, the occurrence of a biochemical relapse, i.e., a fall in her serum phosphorus and calcium concentrations and a rise in her serum alkaline phosphatase, observed the fifth and sixth month after cessation of the parenteral calcium infusion program, indicates that the recovery obtained was the consequence of this particular treatment program.

The present results are significant. Because they provide, for the first time, an alternative and effective therapeutic model for those patients with hereditary resistance to $1,25(\mathrm{OH})_{2} \mathrm{D}$ who are, or have become during the course of their disease, refractory to high-dosage treatment with vitamin $\mathrm{D}$ derivatives. The route of intermittent parenteral administration of calcium must be selected according to the availability of the required facilities and the urgency of active therapy. Calcium infusion via an intracaval catheter provides greater comfort for the child, with no repeated punctures and total freedom of movement, even during sleep. However, such a route can only be used transiently and usually for no longer than 6-9 mo. It also requires adherence to strict rules of asepsis. Consequently, parenteral calcium infusions via an intracaval catheter should never be used in departments that do not possess a highly specialized unit with a medical and nursing staff trained for such treatment. To date, hemodialysis centers are much more numerous and widespread than parenteral nutrition units. Hence, it can be assumed that; for most patients, the route of administration selected will be an arteriovenous fistula. The one inconvenience of this route is that a delay of $2-4$ wk is usually necessary before the fistula can be used.

The present data also have theoretical implications. Bone is one of the major target tissues of $1,25(\mathrm{OH})_{2} \mathrm{D}_{3}(27,28)$, and specific binding of this metabolite to bone cells has been recently documented (36). It is also well established that $1,25(\mathrm{OH})_{2} \mathrm{D}_{3}$ stimulates osteocalcin synthesis $(37)$, and $25(\mathrm{OH}) \mathrm{D}_{3}-24$ hydroxylase (38). Previous studies on cultured fibroblasts from our patient showed abnormalities in cytosol binding and nuclear uptake of $\left[{ }^{3} \mathrm{H}\right] 1,25(\mathrm{OH})_{2} \mathrm{D}_{3}(10)$. The present investigations with the patient's bone-derived cell cultures demonstrate the total ineffectiveness of $1,25(\mathrm{OH})_{2} \mathrm{D}_{3}$ in stimulating $25(\mathrm{OH}) \mathrm{D}_{3}$-24-hydroxylase activity and BGP synthesis. Thus, these observations confirm the presence of an abnormal $1,25(\mathrm{OH})_{2} \mathrm{D}_{3}$ receptoreffector system in her bone cell. Moreover, they show that this abnormality was still present 3 mo after effective healing of her rickets and osteomalacia. While it has been demonstrated in animal studies that vitamin $D$, and more specifically $1,25(\mathrm{OH})_{2} \mathrm{D}_{3}$, is not directly necessary for bone growth and mineralization (39-41), such a demonstration had not been made in man. In 1973, Popovtzer et al. (42) showed that intravenous administration of calcium and phosphorus on alternate days, without supplementary vitamin $D$, could be successfully used to treat the osteomalacia due to vitamin $\mathrm{D}$ deficiency in two adult patients. However, methods for the measurement of circulating concentrations of vitamin $D$ metabolites were not available at that time. Hence, it was not possible to verify that these patients had no circulating $1,25(\mathrm{OH})_{2} \mathrm{D}_{3}$ and to eliminate a possible permissive role of this metabolite in bone mineralization, independent of its action on calcium homeostasis. If such a role, which still remains to be demonstrated, does exist, it must be via a mechanism that does not involve the hormone receptor-effector system. In effect, our data provide convincing evidence that, in humans, normal mineralization can be achieved even in the absence of a normal $1,25(\mathrm{OH})_{2} \mathrm{D}_{3}$ receptor-effector system, provided that normal circulating calcium and phosphorus concentrations are maintained.

\section{Acknowledgments}

We thank Drs. M. Touhami and G. Boudra (Oran, Algeria), who referred the patient and have been following up on her since her return home. We are indebted to Dr. O. Parkes for revising the English of our text, and wish to acknowledge the skillful secretarial assistance of Mrs. M. Poitou.

\section{References}

1. Marx, S. J., U. A. Liberman, C. Eil, G. T. Gamblin, D. A. Degrange, and S. Balsan. 1984. Hereditary resistance to 1,25-dihydroxy-vitamin D. Rec. Prog. Horm. Res. 40:589-620.

2. Pike, J. W., S. Dokoh, H. R. Haussler, U. A. Liberman, S. J. Marx, and C. Eil. 1984. Vitamin $D_{3}$-resistant fibroblasts have immunoassayable 1,25-dihydroxyvitamin $D_{3}$ receptors. Science (Wash. DC). 224:879-881.

3. Brooks, M. H., N. H. Bell, L. Love, P. H. Stern, E. Orfei, S. F. Queener, A. J. Hamstra, and H. F. DeLuca. 1978. Vitamin D-dependent rickets type II. Resistance of target organs to 1,25-dihydroxyvitamin D. N. Engl. J. Med. 298:996-999.

4. Brooks, M. H., P. H. Stern, and N. H. Bell. 1980. Vitamin Ddependent rickets type II. N. Engl. J. Med. 302:810. (Letter)

5. Marx, S. J., A. M. Spiegel, E. M. Brown, D. G. Gardner, R. W. Down, Jr., M. Attie, A. J. Hamstra, and H. F. DeLuca. 1978. A familial syndrome of decrease in sensitivity to 1,25-dihydroxy-vitamin D. J. Clin. Endocrinol. Metab. 47:1303-1310.

6. Marx, S. J., E. G. Swart, Jr., A. J. Hamstra, and H. F. DeLuca. 1980. Normal intrauterine development of the fetus of a woman receiving extraordinarily high doses of 1,25-dihydroxyvitamin $\mathrm{D}_{3}$. J. Clin. Endocrinol. Metab. 51:1138-1142.

7. Zerwekh, J. E., K. Glass, J. Jowsey, and C. Y. C. Pak. 1979. An unique form of osteomalacia associated with end organ refractoriness to 1,25-dihydroxyvitamin $\mathrm{D}$ and apparent defective synthesis of 25-hydroxyvitamin D. J. Clin. Endocrinol. Metab. 49:171-175.

8. Tsuchiya, Y., N. Matsua, H. Cho, M. Kumagai, A. Yasaka, T. Suda, H. Orino, and M. Shiraki. 1980. An unusual form of vitamin Ddependent rickets in a child: alopecia and marked end-organ hyposensitivity to biologically active vitamin D. J. Clin. Endocrinol. Metab. 51: 685-690.

9. Kudoh, T., T. Kumagai, N. Uetsuji, S. Tsugawa, K. Oyanagi, Y. Chiba, R. Minami, and T. Nakao. 1981. Vitamin D-dependent rickets: decreased sensitivity to 1,25-dihydroxyvitamin D. Eur. J. Pediat. 137: 307-311.

10. Balsan, S., M. Garabédian, U. A. Liberman, C. Eil, A. Bourdeau, 
H. Guillozo, R. Grimberg, M. J. Le Deunff, M. Lieberherr, P. Guimbaud, M. Broyer, and S. J. Marx. 1983. Rickets and alopecia with resistance to 1,25-dihydroxyvitamin D: two different cellular defects. J. Clin. Endocrinol. Metab. 57:803-811.

11. Liberman, U. A., R. Samuel, A. Halabe, R. Kauli, S. Edelstein, Y. Weisman, S. E. Papapoulos, T. L. Clemens, L. J. Frahen, and J. L. H. O'Riordan. 1980. End-organ resistance to 1,25-dihydroxy-cholecalciferol. Lancet. i:504-507.

12. Beer, S., M. Tieder, D. Kohelet, O. A. Liberman, E. Vure, G. Bar-Joseph, D. Gabizon, Z. U. Borochowitz, M. Varon, and D. Mondai. 1981. Vitamin D resistant rickets with alopecia: a form of end organ resistance to 1,25-dihydroxyvitamin D. Clin. Endocrinol. 14:395-402.

13. Feldman, D., T. Chen, C. Cone, M. Hirst, S. Shani, A. Benderli, and Z. Hochberg. 1982. Vitamin D resistant rickets with alopecia: cultured skin fibroblasts exhibit defective cytoplasmic receptors and unresponsiveness to 1,25(OH $)_{2} \mathrm{D}_{3}$. J. Clin. Endocrinol. Metab. 55:1020-1022.

14. Rosen, J. F., A. R. Fleishman, L. Finberg, A. Hamstra, and H. F. DeLuca. 1979. Rickets with alopecia: an inborn error of vitamin D metabolism. J. Pediat. 94:729-735.

15. Mathieu, M., J. P. Bretaudière, H. M. Galteau, J. Guidollet, P. Lalegerie, M. Bailly, P. Buret, C. Dorche, P. Louisot, and F. Schicle. 1977. Recommandation pour la mesure de l'activité catalytique des phosphatases alcalines dans le sérum humain à $30^{\circ} \mathrm{C}$ (document 3-stade 3). Anal. Biol. Clin. (Paris). 35:271-273.

16. Arnaud, C., H. C. Tsao, and T. Littledike. 1971. Radioimmunoassay of human parathyroid hormone in serum. J. Clin. Invest. 50 21-34.

17. Preece, M. A., J. L. H. O’Riordan, D. E. M. Lawson, and E. Kodicek. 1974. A competitive protein binding assay for 25 -hydroxycholecalciferol and 25-hydroxyergocalciferol in serum. Clin. Chim. Acta. 54: 235-242.

18. Shepard, R. M., R. L. Horst, A. J. Hamstra, and H. F. DeLuca. 1979. Determination of vitamin $D$ and its metabolites in plasma from normal and anephric man. Biochem. J. 185:55-69.

19. Villanueva, A. R., M. Kujawa, C. H. E. Mathews, and A. M. Parfitt. 1983. Identification of the mineralization front: comparison of a modified toluidine blue stain with tetracycline fluorescence. Metab. Bone Dis. Rel. Res. 5:41-45.

20. Witmer, G., A. Margolis, O. Fontaine, J. Fritsch, G. Lenoir, M. Broyer, and S. Balsan. 1976. Effects of 25-hydroxycholecalciferol on bone lesions of children with terminal renal failure. Kidney Int. 10:395-408.

21. Glorieux, F. H., P. Marie, J. M. Pettifor, and E. E. Delvin. 1980. Bone response to phosphate salts, ergocalciferol and calcitriol in hypophosphatemic, vitamin D resistant rickets. N. Engl. J. Med. 303:10231031.

22. Hodson, E. M., R. A. Evans, C. R. Dunstan, E. E. Hills, and P. F. Shaw. 1982. Quantative bone histology in children with chronic renal failure. Kidney Int. 21:833-839.

23. Richards, G. M. 1974. Modifications of the diphenylamine reaction giving increased sensitivity and simplicity in the estimation of DNA. Anal. Biochem. 57:369-376.

24. Knutson, J. C., and H. F. DeLuca. 1974. 25-hydroxyvitamin $D_{3-}$ 24 hydroxylase. Subcellular location and properties. Biochemistry. 13: 1543-1548.

25. Delmas, P. D., H. W. Wahner, K. G. Mann, and B. L. Riggs. 1983. Assessment of bone turnover in postmenopausal osteoporosis by measurement of serum bone gla-protein. J. Lab. Clin. Med. 102:470476.
26. Price, P. A., and S. K. Nishimoto. 1980. Radioimmunoassay for the vitamin $\mathrm{K}$-dependent protein of bone and its discovery in plasma. Proc. Natl. Acad. Sci. USA. 77:2234-2238.

27. Schnoes, H. K., and H. F. DeLuca. 1980. Recent progress in vitamin D metabolism and the chemistry of vitamin D metabolites. Fed. Proc. 39:2723-2729.

28. Norman, A. W., J. Roth, and L. Orci. 1982. The vitamin D endocrine system: steroid metabolism, hormone receptors, and biological response (calcium binding proteins). Endocr. Rev. 3:331-366.

29. Murer, H., and B. Hildmann. 1981. Transcellular transport of calcium and inorganic phosphate in the small intestinal epithelium. Am. J. Physiol. 240:G409-G416.

30. Allen, L. H. 1982. Calcium bioavailability and absorption: a review. Am. J. Clin. Nutr. 35:783-808.

31. Armbrecht, H. J., and R. H. Wasserman. 1976. Enhancement of $\mathrm{Ca}^{++}$uptake by lactose in the rat small intestine. J. Nutr. 106:12651271.

32. Silver, J., H. Landau, I. Bab, Y. Shvil, M. M. Friedlaender, D. Rubinger, and M. M. Popovtzer. 1985. Vitamin D-dependent rickets types I and II. Diagnosis and response to therapy. Israel J. Med. Sci. 21: 53-56.

33. Hochberg, Z., T. Chen, A. Benderli, S. Shani, C. Cone, and D. Feldman. 1982. Vitamin D resistent rickets with deficient skin fibroblasts receptors to $1,25(\mathrm{OH})_{2} \mathrm{D}_{3}$. Pediat. Res. 16:887a. (Abstr.)

34. Eisenberg, E. 1965. Effects of serum calcium level and parathyroid extracts on phosphate and calcium excretion in hypoparathyroid patients. J. Clin. Invest. 44:942-946.

35. Hirst, M. A., H. I. Hochman, and D. Feldman. 1985. Vitamin $D$ resistance and alopecia: a kindred with normal 1,25-dihydroxy-vitamin $D$ binding, but decreased receptor affinity for deoxyribonucleic acid. $J$. Clin. Endocrinol. Metab. 60:490-495.

36. Boivin, G., G. Morel, P. Mesguich, J. W. Pike, M. C. Chapuy, R. Bouillon, M. R. Haussler, P. M. Dubois, and P. J. Meunier. 1984. Ultrastructural-immunocytochemical localization of endogenous steroid and peptide hormones and of steroid receptors in osteoblasts of neonatal mice calvaria. Calcif. Tiss. Int. 36:452a. (Abstr.)

37. Price, P. A., and S. A. Bankol: 1980. 1,25-dihydroxyvitamin $D_{3}$ increases synthesis of the vitamin K-dependent bone protein by osteosarcoma cells. J. Biol. Chem. 255:1160-1163.

38. Tanaka, Y., and H. F. DeLuca. Stimulation of 24,25-dihydroxyvitamin $\mathrm{D}_{3}$ production by 1,25-dihydroxyvitamin $\mathrm{D}_{3}$. Science (Wash. D.C.) $183: 1198-1200$.

39. Holtrop, M. E., K. A. Cox, M. B. Clark, M. F. Holick, and C. S. Anast. 1981. 1,25-dihydroxycholecalciferol stimulates osteoclasts in rat bones in the absence of parathyroid hormone. Endocrinology. 108: 2293-2301.

40. Underwood, J. L., and H. F. DeLuca. 1984. Vitamin D is not directly necessary for bone growth and mineralization. Am. J. Physiol. 246:E493-E498.

41. Weinstein, R. S., J. L. Underwood, M. S. Hutson, and H. F. DeLuca. 1984. Bone histomorphometry in vitamin D-deficient rats infused with calcium and phosphorus. Am. J. Physiol. 246:E499-E505.

42. Popovtzer, M. M., R. Matthay, A. C. Alfrey, M. Block, P. Beck, J. Miles, and E. B. Rowe. 1973. Vitamin D deficiency osteomalacia. Healing of the bone disease in the absence of vitamin $D$ with intravenous calcium and phosphorus infusions. In Clinical Aspects of Metabolic Bone Disease. B. Frame, A. M. Parfitt, and H. Duncan, editors. Excerpta Medica, Amsterdam. 382-387. 